\title{
PENERAPAN MODEL PEMBELAJARAN KOOPERATIF TIPE TEAMS GAMES TOURNAMENT (TGT) UNTUK MENINGKATKAN HASIL BELAJAR SISWA DI KELAS IV SDN 1 LAPAI
}

\author{
Fitriani $^{1)}$, Yoo Eka Yana Kansil ${ }^{2}$. \\ ${ }^{1)}$ SDN 1 Lapai, Kolaka Utara, Indonesia \\ ${ }^{2)}$ Jurusan PGSD, Universitas Halu Oleo, Kendari, Indonesia \\ Email: fitri.ani0304@gmail.com
}

\begin{abstract}
Abstrak: Penelitian ini bertujuan untuk meningkatkan hasil belajar siswa melalui penerapan model pembelajaran Kooperatif tipe TGT materi penjumlahan dan pengurangan pecahan di kelas Kelas IV SD Negeri 1 Lapai. Jenis penelitian ini adalah penelitian tindakan kelas dengan empat tahapan yaitu; 1) perencanaan; 2) pelaksanaan tindakan; 3) observasi dan evaluasi; 4) refleksi. Berdasarkan hasil penelitian dan pembahasan, terjadi peningkatan hasil belajar siswa dari siklus I ke siklus II. Pada siklus I dari 24 orang siswa terdapat 16 orang siswa yang tuntas dengan persentase ketuntasan $66,7 \%$ dengan nilai rata-rata 73,12 yang mencapai KKM. Pada siklus II mengalami peningkatan yaitu dari 24 orang siswa, terdapat 21 orang siswa yang tuntas dengan persentase ketuntasan $87,5 \%$ dengan nilai rata-rata 81,45 telah mencapai standar KKM. Berdasarkan analisis data hasil pengamatan aktivitas mengajar guru melalui penerapan model pembelajaran kooperatif tipe TGT diperoleh persentase pada siklus I dari $64,28 \%$ menjadi $85,71 \%$, sedangkan persentase pada siklus II yaitu dari $92,86 \%$ menjadi $100 \%$. Berdasarkan analisis data hasil pengamatan aktivitas belajar siswa diperoleh persentase pada siklus I dari $58,32 \%$ menjadi $77,6 \%$, sedangkan persentase pada siklus II dari $91,7 \%$ menjadi $100 \%$.
\end{abstract}

Kata Kunci: Cooperative Learning; TGT; Hasil Belajar

\section{THE APPLICATION OF THE TEAMS GAMES TOURNAMENT (TGT) COOPERATIVE LEARNING MODEL TO IMPROVE STUDENT LEARNING OUTCOMES IN CLASS IV SDN 1 LAPAI}

\begin{abstract}
This study aims to improve student learning outcomes through the application of the TGT cooperative learning model, the addition and subtraction material of fractions in the fourth grade class of SD Negeri 1 Lapai. This type of research is a classroom action research with four stages, namely; 1) planning; 2) implementation of the action; 3) observation and evaluation; 4) reflection. Based on the results of research and discussion, there was an increase in student learning outcomes from cycle I to cycle II. In the first cycle of 24 students there were 16 students who completed with a percentage of $66.7 \%$ completeness with an average score of 73.12 who reached the KKM. In the second cycle there was an increase, from 24 students, there were 21 students who completed with a percentage of $87.5 \%$ completeness with an average value of 81.45 who had reached the KKM standard. Based on the analysis of the data from the observation of teacher teaching activities through the application of the TGT type of cooperative learning model, the percentage in cycle I was obtained from $64.28 \%$ to $85.71 \%$, while the percentage in cycle II was from $92.86 \%$ to $100 \%$. Based on the analysis of the data from the observation of student learning activities, the percentage in the first cycle was obtained from $58.32 \%$ to $77.6 \%$, while the percentage in the second cycle was from $91.7 \%$ to $100 \%$.
\end{abstract}

Keywords: Cooperative Learning; TGT; Learning outcomes 


\section{Pendahuluan}

Sekolah dasar merupakan landasan penting mendasar untuk terselenggaranya kegiatan belajar mengajar pada jenjang yang lebih tinggi yaitu pendidikan menengah dan jenjang pendidikan tinggi. Dalam perencanaan pembelajaran, bahwa baik atau tidaknya pemilihan suatu model pembelajaran bergantung pada tujuan pembelajarannya, kesesuaian materi pembelajaran dan tingkat kemampuan serta kondisi siswa. Selain itu kemampuan guru memanfaatkan sumber-sumber belajar lebih menarik dan berkesan dalam benak siswa yang berdampak pada meningkatnya motivasi dan antusias siswa dalam belajar serta menunjang pencapaian hasil belajar secara optimal.

Siswa harus memiliki kemampuan berkomunikasi serta menguasai teknologi informasi dalam kancah globalisasi dan persaingan dalam kerja. Keterampilan berpikir inovatif dalam upaya mengembangkan ilmu, teknologi, dan seni. Siswa harus dibekali dengan kempuan untuk belajar sepanjang hayat, belajar dari aneka sumber, belajar bekerja sama, beradaptasi, dan menyelesaikan masalah. Oleh sebab itu, paradigma pembelajaran harus diubah karena pembelajaran tradisional yang fokus pada penguasaan materi tidak dapat digunakan untuk mempersiapkan siswa untuk berkompetisi pada masa depan. Pendidikan yang dilakukan seharusnya membentuk siswa yang memiliki karakter agar mereka tidak menyalahgunakan pengetahuan dan keterampilanya untuk merugikan orang lain. (Ridwan Sani, 2014: 3-4)

Dari hasil observasi dengan menggunakan teknik wawancara kepada guru kelas IV SD Negeri 1 Lapai, menyatakan bahwa hasil belajar matematika siswa kelas IV pada satu tahun sebelumnya masih rendah yaitu pada semester genap tahun pelajaran 2015/2016. Dengan presentase $52 \%$ atau masih ada 15 siswa yang memiliki nilai di bawah KKM yang telah ditentukan dengan kata lain, siswa yang mencapai KKM sebesar $48 \%$ atau 10 orang siswa dengan rata-rata sebesar 59,82. Berdasarkan ketuntasannya siswa belum dapat dikatakan tuntas. Siswa dikatakan tuntas apabila telah mencapai $(\mathrm{KKM}) \geq 70$. Tolak ukur keberhasilan pembelajaran pada umumnya adalah hasil belajar siswa setelah mengikuti proses pembelajaran. Artinya selama satu tahun terakhir ini sebagian besar siswa belum mencapai KKM. Hal ini disebabkan oleh, 1) kemampuan guru dalam memberikan informasi (materi bahan ajar) kebanyakan menggunakan metode ceramah, 2) kreatifitas dan inovasi guru dalam pembelajaran masih sangat rendah, 3) metode pembelajaran yang cenderung membosankan dan menjenuhkan bagi siswa, 4) Pembelajaran tersebut tidak menggunakan media sebagai alat untuk mengkonkretkan materi pelajaran, sehingga siswa mengalami kesulitan dalam memahami materi mengenai pecahan, dan 5) Motivasi siswa terhadap pembelajaran matematika masih rendah. (Guru Kelas IV).

Hal yang menjadi hambatan dalam pembelajaran matematika adalah disebabkan kurang dikemasnya pembelajaran matematika dengan model pembelajaran yang menarik serta menyenangkan. Para guru sering kali menyampaikan pendidikan matematika menggunakan metode ceramah, sehingga pembelajaran cenderung membosankan dan kurang menarik minat para siswa yang pada giliranya hasil belajar siswa kurang memuaskan.

Menurut Slavin (Putra, 2015) "penggunaan pembelajaran kooperatif dapat meningkatkan prestasi belajar para siswa dan dapat mengembangkan hubungan antar kelompok, penerimaan terhadap teman sekelas yang lemah dalam bidang akademik, dan meningkatkan rasa harga diri". Dari beberapa pendapat tersebut maka penelitian ini menggunakan model pembelajaran kooperatif dalam pembelajaran matematika di kelas. Penerapan model pembelajaran kooperatif tipe Team Games Tournament (TGT) merupakan kegiatan pembelajaran yang menciptakan suasana siswa merasa ambil bagian dan berperan aktif dalam proses pembelajaran. Model pembelajaran tipe Teams Games Tournament (TGT) ini, pada hakekatnya dirancang untuk memberikan kesempatan kepada siswa agar dapat 
belajar melalui kegiatan bermain, berlomba, dan bekerjasama dalam tim. Keberhasilan dari penerapan model pembelajaran kooperatif tipe Teams Games Tournament (TGT) ini tergantung pada peran dan kesiapan guru di dalamnya. Peran guru tersebut sangat tergantung dari kegiatan pembelajaran yang digunakan, juga materi yang sedamg diajarkan.

Melalui diskusi peneliti dengan guru dan kepala sekolah maka diusulkan untuk menerapkan model Teams Games Tournament (TGT) dalam pembelajaran matematika khususnya pada materi pokok penjumlahan dan pengurangan pecahan. Diharapkan melalui model TGT dapat meningkatkan pemahaman dan motivasi siswa terhadap materi tersebut yang pada akhirnya meningkatkan hasil pembelajaran siswa.

Penelitian yang dilakukan Wati, A.A. (2015) enunjukkan bahwa terdapat pengaruh antara model pembelajaran kooperatif tipe TGT (Teams Games Tournament) dengan model pembelajaran konvensional terhadap hasil belajar siswa kelas V tema ekosistem di SDN Babatan I/456 Surabaya.

Masalah dalam penelitian ini adalah: 1) Apakah penerapan model pembelajaran Kooperatif tipe Teams Games Tournament (TGT) dapat meningkatkan hasil belajar siswa pada materi menyelesaikan masalah pecahan di kelas IV SD Negeri 1 Lapai? 2) Apakah penerapan model pembelajaran Kooperatif tipe Teams Games Tournament (TGT) dapat meningkatkan aktivitas belajar siswa pada materi menyelesaikan masalah pecahan di kelas IV SD Negeri 1 Lapai? 3) Apakah penerapan model pembelajaran Kooperatif tipe Teams Games Tournament (TGT) dapat meningkatkan aktivitas mengajar guru pada materi menyelesaikan masalah pecahan d kelas IV SD Negeri 1 Lapai? Tujuan penelitian ini adalah 1) Untuk meningkatkan hasil belajar siswa melalui penerapan model pembelajaran Kooperatif tipe Teams Games Tournament (TGT) pada materi menyelesaikan masalah pecahan di kelas IV SD Negeri 1 Lapai. 2) Untuk meningkatkan aktivitas belajar siswa melalui penerapan model pembelajaran Kooperatif tipe Teams Games Tournament (TGT) pada materi menyelesaikan masalah pecahan di kelas IV SD Negeri 1 Lapai. 3) Untuk meningkatkan aktivitas mengajar guru melalui penerapan model pembelajaran Kooperatif tipe Teams Games Tournament (TGT) pada materi menyelesaikan masalah pecahan di kelas IV SD Negeri 1 Lapai. Penelitian ini diharapkan dapat memberikan manfaat bagi guru, siswa, sekolah dan penelitian lainnya.

\section{Metode}

Jenis penelitian adalah penelitian tindakan kelas (PTK. Penelitian ini dilaksanakan pada semester ganjil tahun pelajaran 2016/2017 di kelas IV SD Negeri 1 Lapai Kab. Kolaka Utara dengan Subyek dalam penelitian ini adalah iswa kelas IV SD Negeri 1 Lapai pada semester ganjil tahun ajaran 2016/2017 berjumlah 25 orang. Penelitian tindakan kelas ini dilaksanakan dalam dua siklus yang terdiri dari empat tahapan yaitu perencanaan, pelaksanaan tindakan, observasi dan evaluasi serta refleksi Jenis data dalam penelitian ini adalah data kualitatif dan kuantitatif. Data kualitatif berupa kegiatan proses pembelajaran aktivitas belajar siswa dan aktivitas guru. Data kuantitatif berupa nilai hasil belajar siswa. Sumber data dalam penelitian ini adalah guru dan siswa Kelas IV SD Negeri 1 Lapai.

Data kualitatif akan dianalisis secara deskriptif kualitatif berdasarkan observasi, sedangkan data kuantitatif dianalisis secara kuantitatif. Sebagai indikator keberhasilan penelitian ini adalah jika materi pelajaran dipahami secara klasikal dan minimal $80 \%$ proses pelaksanaan tindakan telah sesuai dengan skenario pembelajaran. Seorang siswa dikatakan telah mencapai ketuntasan belajar secara perorangan apabila siswa tesebut telah memperoleh nilai minimal 70 . 


\section{Hasil}

\section{Aktivitas Guru}

persentase hasil observasi aktivitas mengajar guru pada mengajar pertama yang terlaksana yaitu 64,28\% dari 14 aspek yang diamati, dengan jumlah skor keseluruhan sebesar 9. Sedangkan data persentase hasil observasi aktivitas mengajar guru pada mengajar kedua yang terlaksana yaitu $85,71 \%$. hasil observasi aktivitas mengajar guru pada mengajar pertama yang terlaksana yaitu $92,86 \%$ dari 14 aspek yang diamati. Sedangkan data persentase hasil observasi kegiatan guru pada mengajar kedua yang terlaksana yaitu $100 \%$ dengan skor hasil yang diperoleh yaitu 14. Berdasarkan indikator keberhasilan yang ditentukan minimal $80 \%$ aktivitas mengajar guru telah terpenuhi.

\section{Aktivitas Siswa}

Data persentase hasil observasi kegiatan belajar siswa pada mengajar pertama yang terlaksana yaitu 58,32\%, dengan jumlah skor hasil aktivitas belajar siswa secara keseluruhan yaitu 21 dari 9 aspek yang diamati. Sedangkan data persentase hasil observasi aktivitas belajar siswa pada mengajar kedua yang terlaksana yaitu 77,6\% dengan jumlah persentase perolehan pada siklus I mencapai $68,03 \%$ dengan perolehan tersebut belum memenuhi standar ketuntasan yang ditentukan minimal $80 \%$ aktivitas siswa telah terpenuhi dengan baik. Skor hasil belajar siswa pada siklus II nampak bahwa aktivitas setiap kelompok tiap mengajar naik mencapai kriteria yang baik dan total keseluruhan aktivitas belajar siswa pada siklus II sebesar 94,45\%. Dengan demikian kriteria aktivitas kelompok siswa telah memenuhi indikator keberhasilan minimal $80 \%$.

\section{Hasil Belajar Siswa}

Hasil belajar dari jumlah siswa keseluruhan 25 orang yang mengikuti tes hanya 24 orang, dan hanya 16 orang yang memperoleh nilai $\geq 70$ atau dengan persentase $66,7 \%$ siswa mencapai KKM, sedangkan 8 orang yang memperoleh nilai di bawah 70 atau dengan persentase $33,3 \%$. Ketuntasan hasil belajar siswa pada siklus II menunjukan hasil belajar seluruh siswa sebanyak 25 yang mengikuti tes hanya 24 siswa. 21 orang siswa yang memperoleh nilai $\geq 72$ atau dengan persentase $87,5 \%$ siswa mencapai KKM, sedangkan 3 siswa yang memperoleh nilai di bawah 72 atau dengan persentase $12,5 \%$. Kenyataan tersebut telah mencapai skor kinerja dari segi hasil belajar yaitu $80 \%$ siswa mencapai nilai $\geq 72$.

\section{Pembahasan}

Menurut IGAK Wardhani (2010: 1.4), penelitian tindakan kelas adalah penelitian yang dilakukan oleh guru di dalam kelasnya sendiri melalui refleksi diri, dengan tujuan untuk memperbaiki kinerjanya sebagai guru, sehingga hasil belajar siswa menjadi meningkat. Pelaksanaan penelitian ini terdiri dari empat kali mengajar yang dibagi menjadi dua siklus. Pada pelaksanaan pembelajaran tiap mengajar terdapat kegiatan yang mencerminkan model pembelajaran Kooperatif tipe TGT yang terdiri dari 5 tahap yaitu: Class Presentation/penyajian kelas yaituguru menjelaskan secara singkat materi yang akan diajarkan menggunakan ceramah bervariasai., Teams/kelompok yaitu siswa mengerjakan soal-soal dalam bentuk kelompok secara kompak, bekerja sama dan setiap individu bertanggungjawab atas soal-soal tersebut, Games/ permainan yaitu sebuah permainan yang dirancang oleh guru untuk menguji pemahaman siswa dari penyajian kelas dan belajar secara kelompok, Tournament pertandingan yaitu kegiatan yang dilakukan setelah selesai satu unit pembelajaran atau diakhir minggu untuk menguji kemampuan siswa dari penyajian kelas dan belajar kelompok, Team Recognizel penghargaan kelompok yaitu guru memberikan penghargaan kelompok bukan pada individu berupa piagam penghargaan.

Berdasarkan permasalahan pertama tentang bagaimana penerapan model pembelajaran Kooperatif tipe TGT dalam pembelajaran matematika pada materi penjumlahan 
dan pengurangan pecahan. Untuk mengatasi rendahnya hasil belajar siswa pada siklus I, peneliti melakukan diskusi dengan observer dan disepakati adanya beberapa kelemahan guru dalam pengelolaan model pembelajaran Kooperatif tipe TGT di kelas khususnya penjumlahan dan pengurangan pecahan, yaitu:

1. Guru belum dapat menggunakan waktu dengan baik.

2. Guru belum dapat membimbing siswa pada saat kerja kelompok sehingga masih ada siswa yang bersikap individulisme.

3. Guru masih kurang menguasai modelpembelajaran Kooperatif tipe TGT, sehingga proses pembelajaran belum berjalan dengan baik.

Dari hasil refleksi tersebut kemudian ditentukan langkah-langkah perbaikan pada siklus II sebagai berikut:

1. Guru harus menggunakan waktu dengan baik agar proses pembelajaran dapat berlangsung sesuai dengan yang telah direncanakan.

2. Guru harus dapat membimbing siswa dalam belajar kelompok agar siswa dapat saling kompak dan bekerjasama dalam kelompok.

3. Guru harus lebih menguasai konsep penerapan model pembelajaran Kooperatif tipe TGT.

Berdasarkan hasil analisis dan refleksi tersebut, guru melakukan perbaikan-perbaikan untuk diterapkan pada siklus II serta memperbaharui cara menyampaikan materi pembelajaran dengan selalu melibatkan siswa dalam kegiatan pembelajaran dalam hal penemuan masalah yang diberikan, sehingga diharapkan dengan pembelajaran tersebut akan merangsang cara berpikir kognitif siswa untuk selalu melakukan penemuan.

Berdasarkan tes hasil belajar siswa pada siklus I secara klasikal mencapai persentase ketuntasan yaitu $68,23 \%$ ketuntasan ini belum mencapai target peneliti yaitu persentase hasil belajar siswa belum mencapai $80 \%$. Sedangkan pada siklus II target ketuntasan siswa telah tercapai yaitu $87,5 \%$ siswa telah tuntas dalam pembelajarannya. Hal ini peneliti dianggap telah berhasil mencapai targetnya. Dalam penelitian ini keberhasilan siswa dalam tes hasil belajar ini memberikan gambar bahwa dengan menerapkan model Kooperatif tipe TGT mampu meningkatkan hasil belajar siswa.

Adanya motivasi dan minat belajar siswa yang cukup tinggi tersebut, disebabkan karena dalam model pembelajaran Kooperatif tipe TGT siswa dituntut untuk dapat saling bekerjasama dalam kelompok dan kekompakan dalam kelompok pada saat pertandingan. Hal ini sebagaimana wawancara yang dilakukan peneliti bersama beberapa orang siswa di kelas IV pada akhir pembelajaran, menyatakan bahwa pembelajaran dengan model pembelajaran Kooperatif tipe TGT sangat menyenangkan, dikarenakan siswa tidak hanya dapat ilmu sendiri melainkan mereka saling mengajarkan antara teman yang satu dengan teman yang lain dan mereka dapat bermain dalam proses pembelajaran sehingga membuat mereka tidak merasa bosan.

Peningkatan rata-rata aktivitas siswa pada setiap siklus tersebut menandakan bahwa siswa mulai aktif dalam mengikuti pembelajaran. Hasil observasi yang dilakukan peneliti menunjukkan bahwa pelaksanaan pembelajaran dengan menerapan pembelajaran Kooperatif tipe TGT dapat memberikan hasil yang lebih baik walaupun masih terdapat beberapa aktivitas yang tidak mengalami peningkatan yang signifikan dan tergolong dalam kategori cukup.

Berdasarkan hasil analisis deskriptif terhadap aktivitas belajar siswa pada setiap siklus menunjukkan bahwa dengan menerapkan model pembelajaran Kooperatif tipe TGT mampu meningkatkan aktivitas belajar siswa sehingga tampak bahwa pembelajaran yang dilakukan dalam penelitian ini lebih terpusat pada siswa (student center), dimana peran guru dalam pembelajaran hanya bersifat sebagai fasilitator.

Pada siklus I aktivitas belajar siswa dianggap baik walaupun masih banyak terdapat kekurangan-kekurangan seperti siswa masih kurang aktif dalam kelompoknya, siswa banyak 
bermain dalam kegiatan diskusi, sehingga membuat teman yang lain terganggu, beberapa siswa masih belum mampu mempertanggungjawabkan soal-soal pada saat berdiskusi dalam kelompok. Beberapa kekurangan itu kemudian direfleksi dan dilakukan beberapa perbaikan untuk pelaksanaan tindakan pada siklus II. Sehingga kegiatan pembelajaran yang pada siklus II berjalan dengan baik. Hal ini terlihat pada aktifitas siswa dalam pelaksanaan pembelajaran siklus II dan ketuntasan hasil belajar siswa yaitu $87,5 \%$ telah mencapai target indikator keberhasilan peneliti yaitu $80 \%$.

Sehingga dari uraian di atas membuktikan bahwa dengan menerapkan model pembelajaran Kooperatif tipe TGT dapat meningkatkan aktivitas mengajar guru dan aktivitas belajar siswa serta meningkatkan hasil belajar siswa pada materi menyelesaikan masalah pecahan di kelas IV SD Negeri 1 Lapai.

Jika ditinjau dari pendukung pengembangan KTSP yang tercantum dalam Depdiknas (2003: 25) pembelajaran kooperatif model TGT merupakan model pembelajaran yang benarbenar efektif dan efisien. Berikut ini analisis penerapan pembelajaran kooperatif model TGT terhadap prinsip pendukung pengembangan KTSP:

1. Berpusat pada siswa.

Dalam TGT siswa diposisikan sebagai subjek belajar, artinya yang melaksanakan kegiatan belajar mengajar adalah siswa. Kegiatan belajar mengajar dengan model pembelajaran kooperatif tipe TGT ini dilakukan dengan melakukan turnamen yaitu saling menanyakan antar anggota kelompok, sehingga konsep diperoleh berdasarkan hasil diskusi dalam masing-masing kelompok dan guru hanya bertindak sebagai fasilitator.

2. Mengembangkan kreatifitas siswa.

Kegiatan belajar mengajar perlu dipilih dan dirancang agar memberikan kesempatan siswa untuk berkreasi secara berkesinambungan guna mengembangkan dan mengoptimalkan kreatifitas siswa. Pada model pembelajaran kooperatif tipe TGT pengembangan kreativitas ini terwujud dengan pemberian tugas individu siswa untuk membuat pertanyaan sekaligus jawaban secara bebas sesuai dengan kemampuan masing-masing.

3. Menciptakan kondisi menyenangkan dan menantang.

Proses pembelajaran dalam model pembelajaran kooperatif tipe TGT dilaksanakan oleh setiap kelompok sehingga dapat berjalan lebih rileks. Suasana belajar yang menyenangkan sangat diperlukan karena otak tidak akan bekerja secara optimal bila perasaan dalam keadaan tertekan. Selain itu dalam tournament pada proses pembelajaran kooperatif tipe TGT setiap siswa bersaing untuk memperoleh nilai yang setinggi-tingginya, sehingga dengan persaingan tersebut siswa akan merasa lebih tertantang untuk menjadi yang terbaik.

4. Mengembangkan beragam kemampuan yang bermuatan nilai.

Siswa akan belajar secara optimal jika pengalaman belajar yang disajikan dapat mengembangkan berbagai kemampuan seperti kemampuan logis matematis, bahasa, musik, kinestetik, dan kemampuan inter ataupun intra personal. Pengembangan kemampuan dalam model pembelajaran kooperatif tipe TGT terbukti dengan adanya tugas membuat pertanyaan, kerjasama untuk saling melengkapi dalam memperoleh konsep yang benar dan adanya kebiasaan untuk berusaha memahami siswa lain.

5. Menyediakan pengalaman belajar yang beragam.

Keragaman pengalaman belajar menuntut keragaman penyediaan sumber belajar, keragaman cara penilaian, keragaman tempat belajar, keragaman waktu, dan keragaman organisasi kelas. Pengalaman belajar juga menyediakan proporsi yang seimbang antara pemberian informasi dan penyajian terapannya. Model pembelajaran kooperatif tipe TGT memberikan pengalaman yang sangat beragam pula, diantaranya cara memberikan penjelasan kepada orang lain, melakukan penilaian, dan cara bekerjasama dalam suatu tim. Penyediaan 
proporsi yang seimbang dalam model pembelajaran kooperatif tipe TGT terbukti adanya perlengkapan konsep oleh guru yang memerlukan adanya tambahan media.

6. Belajar melalui berbuat.

Melalui model pembelajaran kooperatif tipe TGT siswa belajar berbuat untuk memperoleh konsep dengan bekerjasama dalam setiap kelompok. Hasil belajar akan meningkat bila kegiatan pembelajaran dalam model pembelajaran kooperatif tipe TGT dikondisikan sedemikian rupa supaya siswa melakukan kegiatan praktis, seperti penggunaan telinga untuk mendengarkan penjelasan teman..

\section{Simpulan}

Penerapan model pembelajaran kooperatif tipe TGT dapat meningkatkan hasil belajar siswa pada materi menyelesaikan masalah pecahan. Hal ini dapat ditunjukan oleh hasil tes siklus, nilai rata-rata siswa pada siklus I yaitu 73,65 mengalami peningkatan pada siklus II dengan nilai rata-rata 80,17 dengan persentase ketuntasan siswa pada siklus I hanya 69,23\% dengan jumlah siswa 26 yang tuntas 18 siswa meningkat menjadi 87,5\% pada siklus II dengan jumlah siswa yang tuntas mencapai 21 orang dari 24 siswa. 2) Penerapan model pembelajaran kooperatif tipe TGT dapat meningkatkan aktivitas belajar siswa pada materi menyelesaikan masalah pecahan. Hal ini dapat ditunjukan oleh lembar observasi aktivitas belajar siswa. Aktivitas belajar siswa pada siklus I mengajar pertama yaitu 58,32\% meningkat menjadi 77,6\% pada mengajar kedua. Aktivitas belajar siswa pada siklus II mengajar pertama 91,7\% meningkat menjadi $100 \%$ pada mengajar kedua. 2) Penerapan model pembelajaran kooperatif tipe TGT dapat meningkatkan aktivitas mengajar guru pada materi menyelesaikan masalah pecahan. Hal ini dapat ditunjukan oleh lembar observasi aktivitas mengajar guru. Aktivitas mengajar guru pada siklus I mengajar pertama yaitu $64,28 \%$ meningkat menjadi $71,42 \%$ pada mengajar kedua. Aktivitas mengajar guru pada siklus II mengajar pertama 92,86\% meningkat menjadi $100 \%$ pada mengajar kedua

\section{Referensi}

Departemen Pendidikan Nasional. 2003. Pedoman Khusus Pengembangan Instrumen dan Penilaian Ranah Kognitif, Afektif dan Psikomotor. Jakarta: Depdiknas-Dikdasmen.

Putra, F.G. 2015. Eksperimentasi Model Pembelajaran Kooperatif Tipe Teams Games Tournamen (TGT) Berbantu Software Cabri 3d Ditinjau dari Kemampuan Koneksi Matematika. Al-Jabar: Jurnal Pendidikan Matematika Vol. 6 No. 2http://ejournal.radenintan.ac.id/index.php/al-jabar/article/view/43/37

Ridwan Sani. 2014. Pembelajaran saintifik untuk Kurikulum 2013. Jakarta: Bumi Aksara.

Suparno. 2008. Riset Tindakan Untuk Pendidikan. Jakarta: Grasindo.

Wati, A.A. 2015. Pengaruh Model Pembelajaran Kooperatif Tipe TGT (Teams Games Tournament) Terhadap Hasil Belajar Siswa Kelas V Tema 8 Di SDN Babatan I/456 Surabaya. Jurnal Penelitian Pendidikan Guru Sekolah Dasar (JPGSD) https://www.neliti.com/id/publications/254301/pengaruh-model-pembelajarankooperatif-tipe-tgt-teams-games-tournament-terhadap

Wardani, IGK, dkk. 2008. Penelitian Tindakan Kelas. Jakarta: Universitas Terbuka. 